\title{
An Empirical Study on the Impact of drug licensing on sales
}

\author{
Wang Qihang ${ }^{1, a}$, Cao Chen ${ }^{2, b}$, Hu Yuanjia ${ }^{2, c}$ \\ ${ }^{1}$ Chongqing College of Electronic Engineering, Chongqing, China \\ ${ }^{2}$ Institute of Chinese Medical Sciences, University of Macau, Macau,China \\ awang_qihang@126.com, bkrt-1979@163.com, 'huyuanjia@hotmail.com
}

Keywords: drug licensing; sales; T-test; Q-test

\begin{abstract}
To study the impact of drug licensing on its sales, and to provide a reference for drug development and corporation between pharma. METHODS: Based on the variables "license station", "co-development or co-marketing", "licensor in accord with key marketing company or not" and "time for drug licensing" which reflected drug licensing and sales, with SPSS statistical software, T-test and Q-test of drug licensing and the sales of drugs were carried out on the 151 sample drugs collected in IMS Health. RESULTS \& CONCLUSIONS: Drugs with licensing activities have higher sales than those without licensing. There is no significant difference between co-development and co-marketing for the drugs, Licensor hold the key marketing right helps improve sales of drugs. The optimum time for drug licensing is phase III.
\end{abstract}

\section{Purpose of research}

Drug licensing is a common way used by pharmaceutical enterprises, including the transfer of molecular entities, technology, patent development transference, production and marketing rights [1]. Facing the dilemma of innovation and marketing, an increasing number of pharmaceutical companies try to reduce risks and gain more profits through the method of co-development and co-marketing. Over the recent decade, frequent licensing activities between chemical pharmaceutical manufacturers, biotechnology companies, contract research organizations and commercial companies have formed the concept of big pharma [2]. In this system, co-development can enhance development benefits by utilizing the innovation advantages of all parties [3]. Enterprises with co-marketing expand the sales force through the complementarity of product lines and the sharing of channel resources [4]. This paper aims to study the influence of drug licensing on sales, four problems will be discussed: (1) whether the drug a licensing can affect sales; (2) Which licensing mode is more beneficial for sales to choose co-development or co-marketing; (3) whether the original research enterprise should master the marketing right; (4) the influence of licensing development time on sales.

\section{Data and Methods}

From the World Review of IMS Health database, this paper selected the top 150 patented drugs and the top 50 biopharmaceuticals in world sales from 2005 to 2009, excluding duplicated drugs and drugs without R\&D information. A total of 151 drugs were collected as research samples.

Extract marketing time, authority-holders, transferees, R\&D history and sales data from 2005 to 2009 from each drug's R\&D profile. According to the information of R\&D profiles and the intention of this paper, four variables are selected: "licensing station", "co-development or co-marketing", "licensor in accord with key marketing company or not" and "time for licensing"

The average marketing time of sample drugs was 1998. Generally, they had reached the mature stage of sales in 5-10 years, so the samples had become mature between 2005 to 2009. Thus this paper takes the average of these five years' sales as the drug sales target.

Firstly, in order to determine whether there is a significant correlation between variables (the significant level is $\mathrm{P}<0.05$ ), independent-sample $\mathrm{T}$ test for the average sales of samples 
corresponding to the three indicators of "licensing station", "co-development or co-marketing", "licensor in accord with key marketing company or not" is conducted by SPSS22.00.Then, one-way ANOVA is conducted for the average sales corresponding to the classification variable of "licensing time" to determine the significance of the difference between groups, If $\mathrm{P}<0.05$, LSD method is used to compare the average number of samples in pairs, i.e., Q test, to determine whether the impact of different intervention time on sales was significant.

\section{Empirical results and analysis}

\subsection{Whether license station can affect drug sales}

Table 1 Group Statistics (Unit: million dollars, same as below)

\begin{tabular}{lllllll}
\hline & $\begin{array}{l}\text { License } \\
\text { station }\end{array}$ & $\mathrm{N}$ & Mean & $\begin{array}{l}\text { Std. } \\
\text { Deviation }\end{array}$ & $\begin{array}{l}\text { Std. } \\
\text { Mean }\end{array}$ & Error \\
\hline \multirow{2}{*}{ Sales } & yes & 122 & 1903.46 & 1699.073 & 153.827 & \\
& no & 29 & 1227.10 & 994.047 & 184.590 & \\
\hline
\end{tabular}

As can be seen from table 1, there were 122 authorized activities in the process of drug development, with an average sales 1.903 billion dollars. There are 29 unlicensed drugs with average sales of 1.23 billion dollars.

Table 2 Independent Samples Test

\begin{tabular}{cllllllllll}
\hline \multicolumn{10}{c}{ Variance } \\
consistency test
\end{tabular}

Following information can be found from table 2 , F value 4.27 , significance $\mathrm{P}=0.041<0.05$, and variance heterogeneity. The second row of data was selected as the result of the analysis, $t$ value 2.815 , significance $\mathrm{P}=0.006<0.05$, indicating that at the significance level of 0.05 , the two groups' average sales was significantly different, and the sales of drugs with licensing activities have higher sales than those without licensing.

\subsection{Influence of co-marketing/co-development on sales}

From table 3, we can find that there are 43 drugs had only signed co-marketing agreements, whose average sale is $\$ 1.63$ billion. And 79 drugs had signed co-development agreements, whose average sale is $\$ 2.05$ billion.

Table 3 Group Statistics

\begin{tabular}{lllllll}
\hline & Station & N & Mean & $\begin{array}{l}\text { Std. } \\
\text { Deviation }\end{array}$ & $\begin{array}{l}\text { Std. } \\
\text { Mean }\end{array}$ & Error \\
\hline Sales & o-marketing & 43 & 1630.18 & 1359.900 & 207.383 & \\
& co-development & 79 & 2052.20 & 1849.040 & 208.033 & \\
\hline
\end{tabular}

\subsection{The licensor in accord with key marketing company or not influent the sales}

According to table 4 , the $\mathrm{F}$ value is 0.758 , the significance $\mathrm{P}=0.386>0.05$, the homogeneity of variance. The first row of data was selected to analysis. $T$ value is -1.315 , significance $\mathrm{P}=0.191>0.05$, which indicate that there was no significant difference in average sales between the two groups at significance level of 0.05 . Drug sales under co-development agreements are slightly higher than those under co-marketing, but the results of two models are not significant. 
Table 4 Independent Samples Test

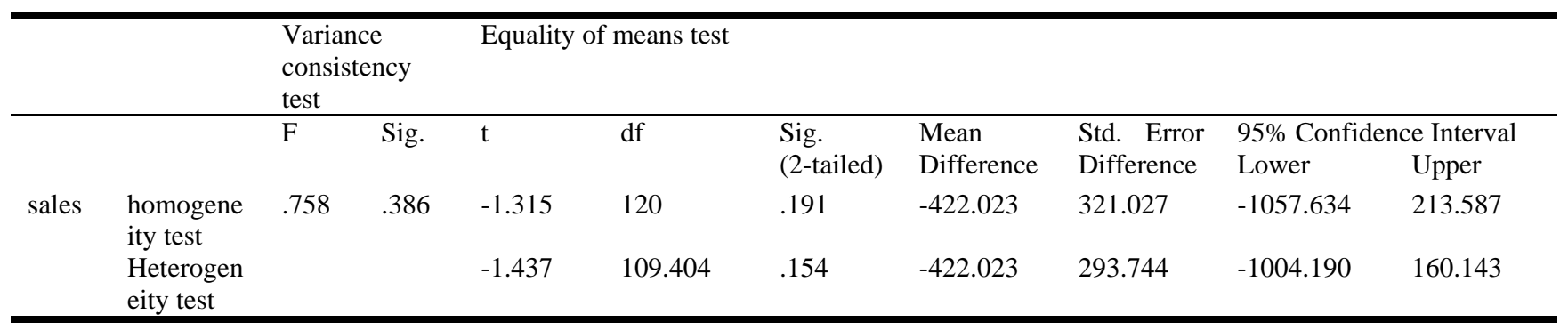

Based on table 5, there are 72 drugs that are mainly marketed by the licensor in the sample, with an average sale of $\$ 2.22$ billion. The situations are different about another 50 drugs, with an average sale of $\$ 1.45$ billion.

Table 5 Group Statistics

\begin{tabular}{|c|c|c|c|c|c|c|}
\hline & $\begin{array}{l}\text { licensor / } \\
\text { marketing } \\
\text { company }\end{array}$ & key & $\mathrm{N}$ & Mean & $\begin{array}{l}\text { Std. } \\
\text { Deviation }\end{array}$ & $\begin{array}{l}\text { Std. } \\
\text { Mean }\end{array}$ \\
\hline sales & $\begin{array}{l}\text { same } \\
\text { different }\end{array}$ & & $\begin{array}{l}72 \\
50\end{array}$ & $\begin{array}{l}2219.28 \\
1448.68\end{array}$ & $\begin{array}{l}1971.420 \\
1067.565\end{array}$ & $\begin{array}{l}232.334 \\
150.976\end{array}$ \\
\hline
\end{tabular}

\subsection{Influence of time for drug licensing on sales}

As can be seen from table 6, F value 2.81, significance $\mathrm{P}=0.096>0.05$, homogeneity of variance. The first row of data was selected to analysis, $T$ value 2.517 , significance $\mathrm{P}=0.013<0.05$, which indicate the average sales of the two groups of samples was significantly different at the significance level of 0.05 . For the original researchers, the sales of drugs with the main marketing right is obviously higher than those without the marketing right.

Table 6 Independent Samples Test

\begin{tabular}{|c|c|c|c|c|c|c|c|c|c|c|}
\hline & & \multicolumn{2}{|c|}{$\begin{array}{l}\text { Variance } \\
\text { consistency test }\end{array}$} & \multicolumn{7}{|c|}{ Equality of means test } \\
\hline & & F & Sig. & $\mathrm{t}$ & $\mathrm{df}$ & $\begin{array}{l}\text { Sig. } \\
\text { (2-tailed) }\end{array}$ & $\begin{array}{l}\text { Mean } \\
\text { Difference }\end{array}$ & $\begin{array}{l}\text { Std. Error } \\
\text { Difference }\end{array}$ & $\begin{array}{l}95 \% \text { Co } \\
\text { Lower }\end{array}$ & $\begin{array}{l}\text { nce Interval } \\
\text { Upper }\end{array}$ \\
\hline \multirow{2}{*}{ sales } & $\begin{array}{l}\text { homogenei } \\
\text { ty test }\end{array}$ & 2.810 & .096 & 2.517 & 120 & .013 & 770.597 & 306.103 & 164.535 & 1376.659 \\
\hline & $\begin{array}{l}\text { Heterogene } \\
\text { ity test }\end{array}$ & & & 2.781 & 114.134 & .006 & 770.597 & 277.079 & 221.712 & 1319.482 \\
\hline
\end{tabular}

As can be seen from table 7, there are 79 co-development samples, we research five licensing time points: pre-clinical, ClinicalI, ClinicalII, Clinical III, pre-registration. Following numbers are the corresponding sample number and average sales: 29, \$ 1.607 billion; 9, \$1.53 billion; 16, \$1.92 billion; 18, \$3.36 billion; 7, \$1.504 billion.

Table 7 Descriptive

\begin{tabular}{|c|c|c|c|c|c|c|c|c|}
\hline $\begin{array}{l}\text { licensing } \\
\text { time }\end{array}$ & $\mathrm{N}$ & Mean & $\begin{array}{l}\text { Std. } \\
\text { Deviation }\end{array}$ & Std. Error & $\begin{array}{l}95 \% \text { Confidence } \\
\text { Mean } \\
\text { Lower Bound }\end{array}$ & $\begin{array}{c}\text { Interval for } \\
\text { Upper Bound }\end{array}$ & Minimum & Maximum \\
\hline pre-clinical & 29 & 1607.06 & 943.401 & 175.185 & 1248.21 & 1965.91 & 448 & 3785 \\
\hline clinicalI & 9 & 1530.18 & 824.450 & 274.817 & 896.45 & 2163.91 & 711 & 2985 \\
\hline clinicalII & 16 & 1916.06 & 1208.481 & 302.120 & 1272.10 & 2560.01 & 294 & 4215 \\
\hline clinical III & 18 & 3364.48 & 3142.812 & 740.768 & 1801.59 & 4927.36 & 744 & 13338 \\
\hline $\begin{array}{l}\text { pre-registrat } \\
\text { ion }\end{array}$ & 7 & 1504.31 & 904.254 & 341.776 & 668.02 & 2340.61 & 489 & 2696 \\
\hline total & 79 & 2052.20 & 1849.040 & 208.033 & 1638.04 & 2466.36 & 294 & 13338 \\
\hline
\end{tabular}

By ANOVA, F value 3.419, $\mathrm{P}=0.013<0.05$ which indicate the mean number of samples between groups is not completely equal at the significance level of 0.05 . So we compare the mean number of 
samples in pairs by LSD.

Table 8 ANOVA

\begin{tabular}{llllll}
\hline & Sum of Squares & df & Mean Square & F & Sig. \\
\hline Between Groups & $4.159 \mathrm{E} 7$ & 4 & $1.040 \mathrm{E} 7$ & 3.419 & .013 \\
& & & & & \\
Within Groups & $2.251 \mathrm{E} 8$ & 74 & 3041674.754 & & \\
Total & $2.667 \mathrm{E} 8$ & 78 & & & \\
\hline
\end{tabular}

As shown in table 9, the significant degree $\mathrm{P}$ between the fourth groups and other groups is always less than 0.05 , indicating that at the significant level of 0.05 , the differences between the fourth groups and the other groups were significant. The sales licensed in the stage III stage were significantly higher than those of the other stages (see Fig. 1).

Table 9 Multiple Comparisons

\begin{tabular}{lllllll}
\hline & & Mean Difference & Std. Error & Sig. & \multicolumn{2}{l}{$95 \%$ Confidence Interval } \\
& & I-J) & & & Lower Bound & Upper Bound \\
\hline pre-clinical & 2 & 76.881 & 665.469 & .908 & -1249.10 & 1402.86 \\
& 3 & -308.998 & 543.130 & .571 & -1391.21 & 773.21 \\
& 4 & $-1757.419 *$ & 523.323 & .001 & -2800.16 & -714.67 \\
& 5 & 102.744 & 734.446 & .889 & -1360.67 & 1566.16 \\
\hline clinicalI & 1 & -76.881 & 665.469 & .908 & -1402.86 & 1249.10 \\
& 3 & -385.878 & 726.683 & .597 & -1833.83 & 1062.07 \\
& 4 & $-1834.300^{*}$ & 712.001 & .012 & -3252.99 & -415.61 \\
& 5 & 25.863 & 878.913 & .977 & -1725.41 & 1777.14 \\
\hline clinicalII & 1 & 308.998 & 543.130 & .571 & -773.21 & 1391.21 \\
& 2 & 385.878 & 726.683 & .597 & -1062.07 & 1833.83 \\
& 4 & $-1448.422^{*}$ & 599.238 & .018 & -2642.43 & -254.41 \\
& 5 & 411.742 & 790.335 & .604 & -1163.04 & 1986.52 \\
\hline clinical III & 1 & $1757.419^{*}$ & 523.323 & .001 & 714.67 & 2800.16 \\
& 2 & $1834.300^{*}$ & 712.001 & .012 & 415.61 & 3252.99 \\
& 3 & $1448.422^{*}$ & 599.238 & .018 & 254.41 & 2642.43 \\
& 5 & $1860.163^{*}$ & 776.857 & .019 & 312.24 & 3408.08 \\
\hline pre-registration & 1 & -102.744 & 734.446 & .889 & -1566.16 & 1360.67 \\
& 2 & -25.863 & 878.913 & .977 & -1777.14 & 1725.41 \\
& 3 & -411.742 & 790.335 & .604 & -1986.52 & 1163.04 \\
& 4 & $-1860.163^{*}$ & 776.857 & .019 & -3408.08 & -312.24 \\
\hline
\end{tabular}

*. The mean difference is significant at the 0.05 level.

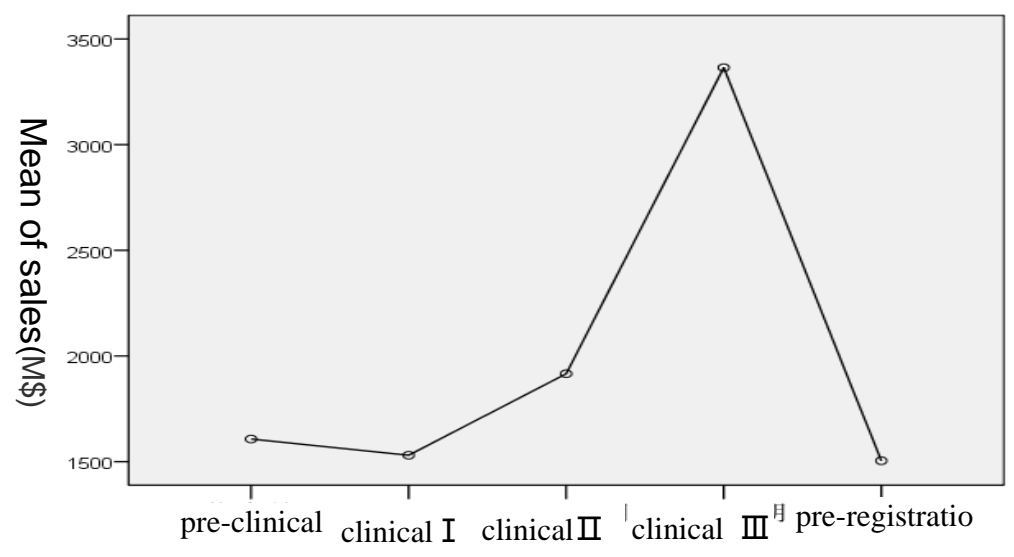

Figure 1 Means Plots 


\section{Discussion and conclusions}

Licensing is a common cooperative activity in the modern pharmaceutical industry, especially in today's emerging environment of biotechnology companies and CROs. Large pharmaceutical groups introduce (License-in) biotechnology companies to cooperate in the development of certain products, and authorize (license-out) compound patents to CRO companies for clinical trials, new dosage forms, new indications development, or grant production rights to generic drug manufacturers, and marketing rights to pharmaceutical Trading companies [2]. This paper discusses the influence of licensing on sales from the perspectives of the authorized person/transferee, $\mathrm{R} \& \mathrm{D} / \mathrm{marketing}$, original researcher/marketer, and licensing time. The following conclusions are drawn:

(1) By authorizing and integrating external resources, the balance of cost, risk and benefit can be achieved, and the sales volume of drugs can be effectively increased. This is in line with the new idea of openly innovation of modern medicine, that is, enterprises use the ideas and knowledge of external innovators to gain innovation in the process of innovation [5]. At the same time, it also accord with the new strategy of modern enterprise market development, that is, enterprises use local enterprises to achieve market share in the process of development.

(2) There is no obvious difference between the two licensing modes of co-development or co-marketing on sales, thus pharmaceutical companies should make decisions to choose the mode according to their actual conditions. Licensing at the development stage can reduce the risk of R\&D, as well as improve the performance of drugs in terms of safety/efficacy and quality control. Co-marketing, on the other hand, can rapidly expand marketing channels, improve market penetration and build brand image.

(3) Original researchers need master the main marketing rights. Technology, commerce and law are the three major factors influencing drug sales: high technology content, mature commercial development and the market monopoly right brought by patent protection, which are the key conditions of the big-selling medicines [6]. The original researchers have both core technologies and corresponding patents, if they can also grasp the right to commercial development or play a leading role in co-marketing, it will certainly promote the sales performance of drugs.

(4) Licensing at the stage of clinical III will benefit enterprises more. Most development licensing agreement occurred early, namely between pre-clinical trials and clinical II[2].The reason is most pharmaceutical companies sign agreement in lower prices for higher uncertainty in early time [7]. But in this paper, the results show that the drugs in the clinical III issue authorization eventually achieve maximum output. The reason is that the drug technology at this stage is relatively mature, the uncertainty and risks are reduced, and the best game point can be found in the cooperation between the two sides, which is of more positive significance to promote drug sales.

For the first time, continuous sales data mean is adopted in this paper, corresponding to different licensing variables, and empirical analysis is carried out to verify the influence of licensing on sales. In fact, there are many factors influencing sales, and licensing is only one of them. This paper is not intended to explain the clear causal and quantitative relationship between licensing mode and sales, nor does it expect to predict sales through licensing data. This analysis is based on the single data of IMS Health, and there are some shortcomings :(1) The sample size is relatively small due to the need to take into account both the R\&D information and the five-years sales data, and most of them are top-ranking drugs;

The rising R\&D cost and the decreasing innovation yield year by year make pharmaceutical development enterprises to adopt new strategies and business models [8]. Enterprises can get a better market performance through technology transfer, market cooperation, and M\&A activities. Thus, reasonable licensing is undoubtedly an effective strategy.

\section{References}

[1] WIPO. Licensing and Technology Transfer in the Pharmaceutical Industry [EB/OL]. http://www.wipo.int/sme/en/documents/pharma_licensing.html. 2012-4-25. 
[2] Kalamas, J., \& Pinkus, G. The optimum time for drug licensing [J]. Nature reviews, Drug discovery. 2009, 2(9), 691-2.

[3] Chesbrough, H., \& Schwartz, K. Innovating business models with co-development partnerships [J]. Research Technology Management. 2007, Jan-Feb, 55-59.

[4] Bucklin, L. P., S. Sengupta. Organizing successful co-marketing alliances [J]. Journal of Marketing. 1993, 57(April), 32-46.

[5] Laursen K, Salter A. Open for innovation: the role of openness in explaining innovation performance among UK manufacturing firms [J]. Strategic Management Journal, 2006, 27(2): 131-150.

[6] Cao Chen, Hu Yuan-jia. Correlation between Composite Index of Patent Value and the Economic Value of Drugs [J]. Chinese Journal of Pharmaceuticals, 2011, 42(7): A62-A64.

[7] Mckinsey Quarterly. The new math for drug licensing [EB/OL]. http://www.mckinseyquarterly.com/The_new_math_for_drug_licensing_1237. 2012-4-25.

[8] Talaga, P. Open innovation: share or die. [J]. Drug Discovery Today. 2009, 14, 1003-1005. 